\title{
Effect of Leadership Style and Power Distance to Work Engagement of Trading Business Employees in Central Java Province After Controlling Age
}

\author{
Fitri Rezeki \\ Pelita Bangsa University, Indonesia \\ \{fitrirezeki@pelitabangsa.ac.id\}
}

\begin{abstract}
The main purpose of this research is finding determinants of work engagement of trading business employees in Central Java. Limitation of determinants for work engagement are only leadership style (that divided into transactional, situational, and transformational), and power distance (that divided into high power distance and low power distance). In order to maintain the credibility of the results calculations, the age of the employees in this study need to be controlled. This research is comparative-quantitative research that comparing 6 groups of employees in $3 \times 2$ matrix from crosses between 3 parts of leadership style and 2 parts of power distance, and making age of employees as covariant. The data collected by questionaries that filled by 249 employees in 35 cities of Central Java province. Data analyzed by anacova that preceded by descriptive statistics calculation and classic assumption test. Based on calculating results, all data are meet the normality test, homogeneity test, and have equality of the regression line. Results of this research as follow: there are significant effect (individual and interaction) of leadership style and power distance to work engagement after controlling age. On simple effect results, work engagement of employees are different after controlling age in case as follow: (1) Between low power distance and high power distance in transactional leadership style; (2) Between low power distance and high power distance in situational leadership style; (3) Between transactional and situational in low power distance condition; (4) Between transactional and transformational in low power distance condition; (5) Between transactional and transformational in low power distance condition.
\end{abstract}

Keywords: Work Engagement, Leadership Style, Power Distance, Age

\section{Introduction}

The main purpose of this research is finding determinants of work engagement of trading business employees in Central Java. There are two main reason to do this research: the important of work engagement in emloyees, and lowing level of work engagement in trading business employees in Central Java.

Work engagement became important for employees because of its large scope (theoritically, work engagement scope is larger than work performance scope). Work engagement is often interpreted as involvement, commitment, passion, enthusiasm, intimacy, affection or absorption, focused effort, and energy [1]. This concept obviously has put humans on nature, the man who needs to be humanized. In other references [3], the employees even trying to exceed the achievements of the targets or limits set. It is not merely to gain compensation (in the form of salary or remuneration) but rather on the psychological satisfaction of employees. In the context of the time, employees who have high work engagement will allocate more time for the job [7]. Work engagement is different from the workaholics [6]. Employees who have 
work engagement does not mean not having engagement with the other context of life. Employees also engage to the other components in life, other than work (eg, family, education, etc.).

Empirically, many employees of small trading business in Central Java province have low level of work engagement. Based on preliminary observations in the 5 trading business in 5 cities in Central Java, it was found that employee engagement has low. Grand tour was conducted by open interview, where the instrument of interview was developed from work engagement instrument, proposed by Baker and Leiter [1]. There are three main indicators of work engagement, namely sincerity work, morale, and sense of belonging.

The problem of low work engagement needs to be solved immediately, because it can cause a variety of negative impacts. Several impacts that can occur due to low level of work engagement are high turnover in the company (which means high recruitment costs), lower customer satisfaction as a result of poor service from a employees, and opportunities for fraud of work that will be done by employees.

The most important thing to solve low level of work engagement is finding its determinant. Rationally, a concept or variable will be influenced by a variety of factors (more than one factor). Similarly, work engagement is also influenced by various factors. This study reviewing for only two factors namely leadership style, and power distance. To make calculation results more credible, variable that considered intrusive need to be controlled. In this case, the controlled variable is the age of the employee.

\section{Literature Review}

\subsection{Leadeship Style}

The research findings show that the effect of the simple effect of leadership style on work engagement seen in transactional leadership style and situational. This is in contrast to studies conducted on the theory Hughes [5] especially regarding the influence of transactional leadership style. Hughes, Ginnett and Curphy [5] favor more transformational than transactional, so these findings reject the theory. However, if we look closely subordinate characteristics studied, it appears that employees of a trading business is a group of people who are not educated (maximum equivalent of high school only) and can not take decisions independently. Therefore, it is necessary that the transactional leader, so that engagement is better (especially when compared to the transformational style).

\subsection{Work Engagement}

Work engagement is often interpreted as involvement, commitment, passion, enthusiasm, intimacy, affection or absorption, focused effort, and energy [1]. This concept obviously has put humans on nature, the man who needs to be humanized. In other references [3], the employees even trying to exceed the achievements of the targets or limits set. It is not merely to gain compensation (in the form of salary or remuneration) but rather on the psychological satisfaction of employees. In the context of the time, employees who have high work engagement will allocate more time for the job [7]. Work engagement is different from the workaholics [6]. Employees who have work engagement does not mean not having engagement with the other context of life. Employees also engage to the other components in life, other than work (eg, family, education, etc.). 


\subsection{Power Distance}

The influence of power distance toward more engagement work described by the theory of Hofstede [2]. According to the study of the theory of Hofstede, power distance can influence employee engagement work, so the findings of this study confirm the theory. The main influence clearly mentions that there are significant power engagement distance to the work of employees after controlling for age. Power distance is proven to improve employee engagement work is a low power distance. This finding is consistent with the results of Heni [4] which states that the power distance needs to be reduced. With the belief that good and tend directly from the employer on the employee, the employee will feel more comfortable, in the sense of having a high work engagement.

\section{Conceptual Framework}

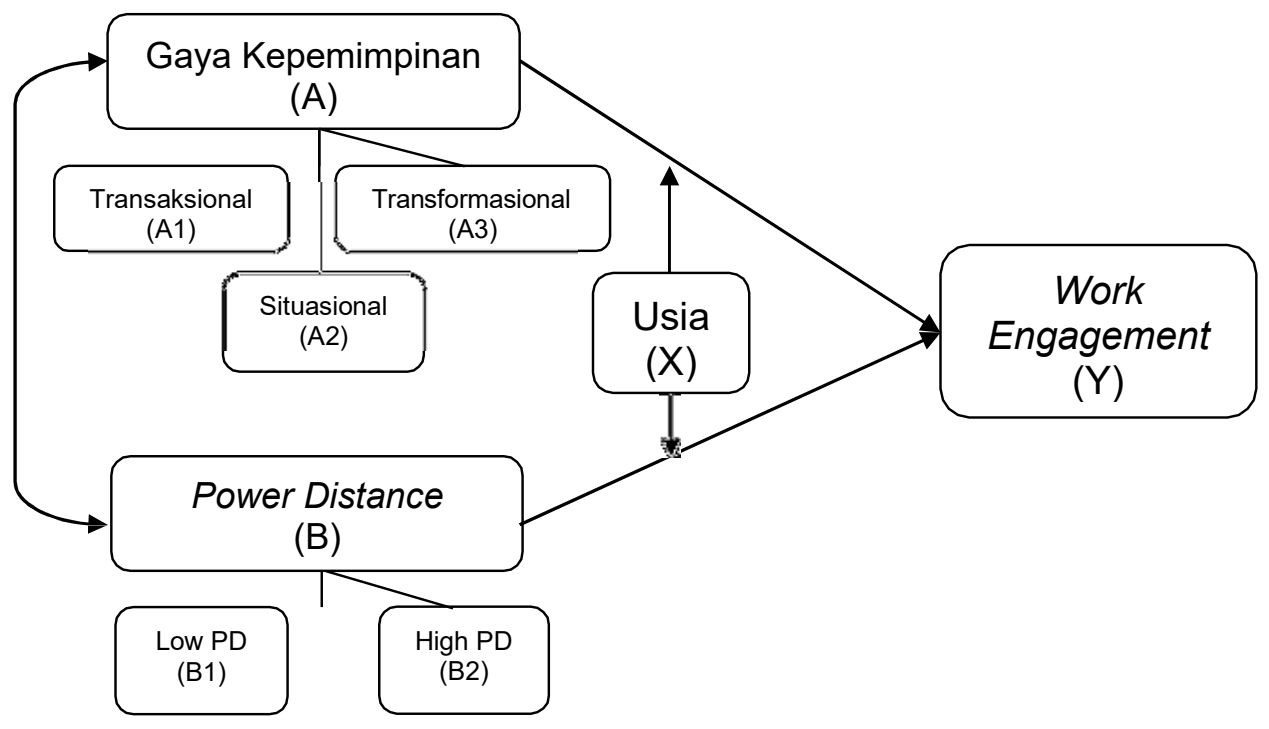

Fig. 1. Conceptual Work

\section{Research Methods}

This research methodology is a comparative quantitative research. The variables were compared in this study is the work engagement of employees in trading business on Central Java province. Leadership style deviding employees into three groups who will be compared. Power distance deviding employees into two groups of employees who will be compared, then based on both of leadership style and power distance there are 6 groups of employees who will be compared. Based on the grouping, the purpose of this study were to determine the influence of 
leadership style and power distance toward work engagement after controlling ages of employees in case: individually (main effect), interaction effect, and simple effect.

The population of this study were all employees of a trading business in Central Java province whose number is unknown. Therefore, samples will be taken as incidental (incidental sampling) to the minimum number of 180 people (30 people for each group in 6 groups of employees) in order to qualify parametric statistical calculations. Factly, there are several groups of employees that contain more than 30 employees, and the total population drawn in this study reached 249 people. Data were collected by questionnaire technique. There are three questionnaires were used. The purposes of two questionnaires are maping gemployees into groups of leadership styles and power distance, and a questionnaire to assess level of employee work engagement. In addition, there is entries of the employees ages in order to obtain data on the age of the employee.

The data were analyzed by various analytical techniques, which include descriptive analysis, classical assumption tests and hypothesis testing. Descriptive analysis includes a calculation of the highest value, lowest value, mean, median, mode, standard deviation, data presentation in the frequency distribution table, and presentation in frequency histograms. Calculation of descriptive analysis was performed for all of the employee groups, that are three groups that divided based on leadership style, two groups that devided by power distance, and both of leadership style and power distance. Furthermore, classical assumption test in this research including data normality, homogeneity, and the equality of the regression line. If all the data passes all three of these calculations in an error rate of 0.05 , then the data may lead to the hypothesis test analysis calculations. There are two techniques performed on hypothesis testing. The main effect hypothesis and interaction effects, will be tested by F-test. Meanwhile, to test the simple effect hypothesis, will do by the t-test.

\section{Results and Discussion}

Currently, the research has been done. Data collection took place in February and May 2019. The object of the study was 249 employees who work in 35 cities at Central Java province. Employee sum was divided into three groups based on leadership style, two groups based on the power distance, and six groups of employees based on both of leadership style and power distance.

Distribution of the number of employees based on the convergence between leadership style and power distance looks as follows.

a) Employees who led by the transactional leaders and work in low power distance organizations (A1B1) as many as 36 people;

b) Employees who led by the transactional leaders and work in high power distance organizations (A1B2) as many as 46 people;

c) Employees who led by the situational leaders and work in low power distance organizations (A2B1) as many as 42 people;

d) Employees who led by the situational leaders and work in high power distance organizations (A2B2) as many as 50 people;

e) Employees who led by the transformational leaders and work in low power distance organizations (A3B1) as many as 33 people;

f) Employees who led by transformational leaders and work in high power distance organizations (A3B2) as many as 42 people. 
Furthermore, based on the leadership style, there are 82 peoples who led by transactional style (A1), 92 peoples who led by situational style (A2), and 75 peoples who led by transformational style (A3). While based on power distance, 111 peoples are work in low power distance organizations (B1), and 138 peoples are work in high power distance organizations (B2). In detail, the distribution of employees in each group looks like Table 1.

Table 1. Distribution of Employees in All of Groups

\begin{tabular}{|c|c|c|c|}
\hline \multirow{2}{*}{ Leadership Style } & \multicolumn{2}{|c|}{ Power Distance } & \multirow[b]{2}{*}{ Total } \\
\hline & Low PD & High PD & \\
\hline Transactional & 36 & 46 & 82 \\
\hline Situational & 42 & 50 & 92 \\
\hline Transformational & 33 & 42 & 75 \\
\hline Total & 111 & 138 & 249 \\
\hline
\end{tabular}

Based on data from the sum of employees, it appears that there is a tendency for employees clustered in a particular group. Based on leadership style, the majority of employees (42 people), led by the situational leaders. While based power distance, most employees are work in high power distance organizations (138 people). Furthermore, based on the both of leadership style and power distance, the majority of employees ( 50 people) led by situational leaders and work in high power distance organizations.

All of the employees have their ages and level of engagement. Work engagement is then processed to obtain the results. The results of the study includes the results of descriptive statistical calculations, the classic assumption test, and the results of hypothesis testing. Here are details of the three results of these studies. As discussed earlier, the results of descriptive statistical calculations including the calculation of the highest value, lowest value, mean, median, mode, standard deviation, as well as the presentation of data in the frequency distributions tables and histograms. Results of calculations that include measures of central tendency and dispersion are presented in Table 2.

Table 2. Results of Calculations for Central Tendency and Dispersion

\begin{tabular}{cccccccc}
\hline Variable & N & Max & Min & Mean & SD & Median & Mode \\
\hline A1 & 82 & 4.13 & 2.06 & 3.20 & 0.508 & 3.203 & 3.146 \\
A2 & 92 & 4.31 & 2.13 & 3.06 & 0.474 & 3.203 & 3.004 \\
A3 & 75 & 4.00 & 2.06 & 3.08 & 0.455 & 3.314 & 3.356 \\
B1 & 111 & 4.31 & 2.06 & 3.29 & 0.500 & 3.099 & 3.215 \\
B2 & 138 & 4.13 & 2.06 & 2.97 & 0.418 & 3.075 & 3.14 \\
A1B1 & 36 & 4.13 & 2.69 & 3.53 & 0.327 & 3.597 & 3.771 \\
A1B2 & 46 & 4.13 & 2.06 & 2.94 & 0.471 & 3.597 & 3.166 \\
A2B1 & 42 & 4.31 & 2.13 & 3.24 & 0.509 & 3.597 & 3.347 \\
A2B2 & 50 & 3.69 & 2.19 & 2.91 & 0.387 & 2.954 & 3.121 \\
A3B1 & 33 & 4.00 & 2.06 & 3.08 & 0.543 & 2.954 & 3.368 \\
A3B2 & 42 & 4.00 & 2.13 & 3.08 & 0.379 & 3.075 & 3.075 \\
\hline
\end{tabular}

Based on table 2, it appears that the value of the highest engagement work is worth 4.31 , and the lowest value of work engagement was 2.06 in a scale of 5. In terms of the average, based on the leadership style, the highest work engagement of employees led by transactional style (3.2), while based on power distance, the highest work engagement is employees who are in conditions of low power distance (3.29), and the highest work engagement that based on a combination of both are employees who led by transactional leaders in conditions of low power distance $(3,53)$.

Although there are differences in the average work engagement of employees in each group 
of leadership style and power distance, these values need to be tested to determine the significance of differences. Hypothesis testing is need to answer this. Based on the study design that has been done, a hypothesis test should be preceded with the classical assumption test. The hypothesis can be tested with parametric statistics if the data meets the assumptions set. Classic assumption test was conducted on the normality test, homogenity test, and equality of the regression line. The following is a presentation of the three calculation of the classical assumption test.

Normality of the data was tested by levene test. Technically, the levene test aims to find the $\mathrm{L}$ count is then compared with $\mathrm{L}$ tables. Based on calculations that have been done, it was found that all these groups of employees (both are divided by leadership style, power distance and combination of both) have L count that is smaller than L tables. Thus, it can be concluded that all of the data are normally distributed. Table 3 below is the result of normality test that has been done. Therefore, it can be seen that the data is feasible to be tested in parametric hypothesis, after tested by another classic assumption test, that are the homogeneity and the equality of the regression line.

Table 3. Results for Normality Test

\begin{tabular}{cccc}
\hline Group & L Count & L table & Result \\
\hline A1 & 0,087 & 0,098 & Normal \\
A2 & 0,063 & 0,092 & Normal \\
A3 & 0,057 & 0,102 & Normal \\
B1 & 0,069 & 0,084 & Normal \\
B2 & 0,069 & 0,075 & Normal \\
A1B1 & 0,096 & 0,148 & Normal \\
A1B2 & 0,102 & 0,131 & Normal \\
A2B1 & 0,081 & 0,137 & Normal \\
A2B2 & 0,099 & 0,125 & Normal \\
A3B1 & 0,100 & 0,154 & Normal \\
A3B2 & 0,082 & 0,137 & Normal \\
\hline
\end{tabular}

Homogeneity of the data was performed using Bartlett's test. There are 3 homogeneity test is done, the test on employees to be grouped based on the leadership style (A1, A2, and A3), tests on employees to be grouped based power distance (B1, B2), and test on employees who are grouped based on the convergence between leadership style and power distance (A1B1, A1B2, A2B1, A2B2, A3B1, and A3B2). Here are the details of the calculation of the three arms of the employee data.

Based on leadership style employees devided into 3 groups: A1, A2, A3, and Bbtäined ${ }^{2}$ count at 0.969 . These values need to be conpled witt ${ }^{2}$ table which is worth 5.99. Als a result $\mathrm{d}^{2} \mathrm{f}^{2}$ count is smaller than ${ }^{2}$ table, it was concluded that the data tend to be homogeneous or qualify homogeneity assumption.In the group of employees who devided based on power distance (B1 and B2), obtained ${ }^{2}$ count amounting to 1.62 . These values need to be compared with ${ }^{2}$ table which is worth 3.84 . As a result that count is smaller than ${ }^{2}$ table, it was concluded that the data tend to be homogeneous or qualify homogeneity assumption.

In the group of employees who grouped based on the convergence between leadership style and power distance (A1B1, A1B2, A2B1, A2B2, A3B1, A3B2), obtained ${ }^{2}$ count amounted to 9,300 . These values need to be compared with ${ }^{2}$ table which is worth-11.07. As a result of $\square^{2}$ count is smaller than table, it was concluded that the data tend to be homogeneous or qualify homogeneity assumption. With the fulfillment of the three basic assumptions of homogeneity of the group of employees divider, then the calculation can be continued in the calculation of the equality for regression line. 
Equality of regression line known through $\mathrm{F}$ test. Based on the calculations that have been done, it was found that the $F$ value of 0.326 which is significant at a p-value of 0.807 . The $p$ value is greater than 0.05 , so it was concluded that the slope of the regression line for all the cells in $2 \times 2$ design has no difference or inclined parallel. With the fulfillment of the terms of normality, homogeneity, and the equality of the regression line, the calculation can be continued in hypothesis testing. Hypothesis testing includes testing for main effects hypothesis, interaction effects hypothesis, and test simple effects hypothesis. There are two main hypotheses influence (main effect) were tested, one hypothesis of interaction (interaction effect) and nine hypotheses simple effect. Here are the results of all these tests of hypothesis.

Main effect hypothesis testing and interaction effects performed by $\mathrm{F}$ test. Based on testing that has been done, the effect of leadership style to work engagement after controlling for ages of employee has a $\mathrm{F}$ value of 3.527 which is significant at 0,031 . While the influence of power distance on work engagement after controlling for age at 30.146 which is significant at 0,000 . Furthermore, the interaction effect between leadership style and power distance after controlling for age, has $\mathrm{F}$ value of 8.867 which is significant at 0,000 .

Tests of Between-Subjects Effects

Dependent Variable: Engagement

Table 4. Results of Main Effect anda Interaction Effect Hypothesis Testing

\begin{tabular}{cccccc}
\hline Source & Type III Sum of Squares & Df & Mean Square & F & Sig. \\
\hline Corrected Model & $10.664^{\mathrm{a}}$ & 6 & 1.777 & 9.169 & .000 \\
Intercept & 129.933 & 1 & 129.933 & 670.275 & .000 \\
X & .121 & 1 & .121 & .624 & .430 \\
A & 1.368 & 2 & .684 & 3.527 & .031 \\
B & 5.844 & 1 & 5.844 & 30.146 & .000 \\
A B & 3.438 & 2 & 1.719 & 8.867 & .000 \\
Error & 46.912 & 242 & .194 & & \\
Total & 2471.852 & 249 & & & \\
Corrected Total & 57.576 & 248 & & & \\
\hline
\end{tabular}

a. R Squared $=.185$ (Adjusted R Squared $=.165$ )

Table 4 shows the values of $\mathrm{F}$ and $\mathrm{p}$-value in the third hypothesis. Based on the table, it appears that all of the hypothesis is accepted in error rate is less than 0.05 . Thus, it can be concluded that there are significant main effects and interaction effect. Due to the significant effect of the interaction, then the hypothesis testing may lead to simple effects hypothesis testing. This test was performed using the t-test. There are 9 hypotheses were tested, the six hypotheses simple effect of leadership style, and three hypotheses simple effect of power distance. The nine hypotheses were tested by t-test, in which the hypothesis will be accepted when the value of $t$ is greater than $t$ table. Table 5 below is the calculation results of hypothesis testing in the ninth simple effect.

Table 5. Results of Simple Effect Hypothesis Testing

\begin{tabular}{ccccc}
\hline No & Sumber Varians & t hitung & t tabel & H $_{\mathbf{0}}$ \\
\hline 1 & A1B1-A1B2 & 4,982 & 1,997 & Reject \\
2 & A2B1-A2B2 & 2,865 & 1,997 & Reject \\
3 & A3B1-A3B2 & 1,027 & 1,997 & Accept \\
4 & A1B1-A2B1 & 2,663 & 1,997 & Reject \\
5 & A1B1-A3B1 & 5,250 & 1,997 & Reject \\
6 & A2B1-A3B1 & 3,026 & 1,997 & Reject \\
\hline
\end{tabular}




\begin{tabular}{ccccc}
\hline No & Sumber Varians & t hitung & t tabel & H $_{\mathbf{0}}$ \\
\hline 7 & A1B2-A2B2 & 0,470 & 1,997 & Accept \\
8 & A1B2-A3B2 & 0,385 & 1,997 & Accept \\
9 & A2B2-A3B2 & 0,851 & 1,997 & Accept \\
\hline
\end{tabular}

Based on Table 5, it appears that there are five accepted hypothesis, namely: (1) Between the transactional leadership style that work in low power distance to transactional leadership style that work in high power distance; (2) Between the situational leadership style that work in low power distance to the situational leadership style that work in high power distance; (3) Between the transactional leadership style that work in low power distance to the situational leadership style that work in low power distance; (4) Between transactional leadership style that work in low power distance to the transformational leadership style that work in low power distance; (5) Between the situational leadership style that work in low power distance to the transformational leadership style that work in low power distance. Results were related to various theories in the interests of refuse and accept existing theories. Some theories is a theory that connects the concept of work engagement and leadership style with theories that link the concept of power distance with work engagement.

\section{Conclusion}

Based on the formulation of the problem have been proposed, and have obtained the research findings, it can be concluded this study. Conclusion The conclusion of research include the influence of the main effects, interaction effects and simple effects. Leadership style and power distance affects both the main (individually) and interaction of the work engagement of employees after controlling for age employees. Moreover, in a simple, transactional and transformational leadership style influence on employee engagement work after controlling for age. In terms of power distance, low power distance engagemnt affect the work of employees after controlling for age.

Based on the research conclusions, it can be suggested several things for the leader of a trading business in order to increase work engagement. The first suggestion is to implement transactional or situational leadership style in leading employees. The second suggestion put forward was to build a low power distance culture in the business. Findings on regarding the effect of transactional and situational style of the work engagement of employees into its own suggestions for further research. In this case, it is recommended that further research conducted a study on the implementation of these two forces in the trading business organization.

\section{References}

[1] Baker B. Arnold., Leiter P. Michael. 2010. Work engagement: A Handbook of Essential Theory and Research. New York: Psychology Press.

[2] Claes Tom., McMahon Frank., Preston S. David. 2008. Education and Leadership. Amsterdam: Radopi.

[3] Gill S. David. 2001. Employee selection and work engagement: do recruitment and selection practices influence work engagement? Kansas State University Press.

[4] Heni Yusri. 2011. Improving Our Safety Culture. Cara Cerdas Membangun Budaya Keselamatan yang Kokoh. Jakarta: Gramedia Pustaka Utama.

[5] Hughes L. Richard., Ginnett C. Robert., Curphy Gordon J. 2012. Leadership: Enhacing The Lesson 
of Experience New York: McGraw-Hill Irwin.

[6] Lu Ying., Samaratunge Ramanie., Hartel Charmine. 2015. Skilled Migration, Expectation and Reality: Chinese Professionals and the lobal labour market. Burlington: Gower Publishing

[7] Luthan Fred. 2011. Organizational Behavior: An Evidence Based Approach. New York: McGraw-Hill Irwin

[8] Purwanto Djoko. 2006. Komunikasi Bisnis. Edisi Ketiga. Jakarta: Erlangga. 